Journal of English Language Teaching

UNNES

\title{
Teaching ESP during emergency remote learning (ERL): Best practices
}

\section{Yuyun Putri Mandasari ${ }^{\bowtie}$, Eka Wulandari}

Poltekkes Kemenkes Malang, Indonesia

$\begin{array}{ll}\text { Article Info } & \begin{array}{l}\text { Abstract } \\ \text { Article History: }\end{array} \\ \text { Received in 1 July } & \begin{array}{l}\text { After a year more of living with COVID-19, the teachers' and students' resilience is } \\ \text { still demanding, particularly regarding language online learning. Both parties must } \\ \text { keep struggling to fulfill the learning requirements in times of crisis. One of the } \\ \text { Approved in 27 July } \\ 2021\end{array} \quad \begin{array}{l}\text { challenges in language issues is teaching English for Specific Purpose (ESP) in higher } \\ \text { education during emergency remote learning (ERL) including teaching ESP at } \\ \text { Published in 28 July }\end{array} \quad \begin{array}{l}\text { Poltekkes Kemenkes Malang in 2020-2021. At these times, ESP teachers have to } \\ \text { design the materials by taking a lot of consideration regarding the students' needs, } \\ \text { goals, learning model, activities, tools, and feedback that met the emergency due to }\end{array} \\ \begin{array}{l}\text { Coronavirus outbreak. They planned, implemented, and evaluated the learning } \\ \text { process until they can find the best ones for the students. This study was a survey } \\ \text { Best Practice }\end{array} & \begin{array}{l}\text { research with 23 participants of ESP lecturers. This article presented some best } \\ \text { practices of teaching ESP in the online mode during ERL as the best experience of } \\ \text { ESP lecturers, in the hope that it will be able to give some new insights for fellow } \\ \text { educators to help them to provide better learning experiences for the students. }\end{array}\end{array}$

${ }^{\square}$ Correspondence Address:

Jalan Besar Ijen No. 77C

Malang, Indonesia

E-mail: yuyunputri1984@gmail.com

p-ISSN 2252-6706 | e-ISSN 2721-4532 


\section{INTRODUCTION}

Emergency Remote Learning (ERL) is such a crucial situation in which the English Language Teaching (ELT) is employed as a temporary response in the middle of crisis and restriction. UNESCO (2020) stated that remote learning strategy is a key element in ensuring continued learning, it is also characterized as the way of teaching interactively through videoconference and the replacement of face-to-face (Waicekawsky et al., 2020). ERL is a short-term solution to the emergent problem and the online courses that are conveyed should not be reflected as a long-term process (Hodges et al., 2020; Misirli \& Ergulec, 2021). After a year more of living with COVID19, the teachers' and students' resilience is still demanding, particularly regarding language online learning. Both parties must keep struggling to fulfill the learning requirements in times of crisis, including the English for Specific Purposes (ESP) teaching in higher education. At these times, ESP teachers have to design the materials by taking a lot of consideration regarding the students' needs, goals, learning model, activities, tools, and feedback that met the emergency due to Coronavirus outbreak. The increased popularity of online ESP teaching and learning during Covid-19 pandemic has forced changes regarding how to deliver the lessons and optimize student participation (Iswati, 2020). The teachers planned, implemented, and evaluated the learning process until they can find the best ones for the students during the online remote learning. These best practices owned by the lecturers became one of the best sources or references to have a successful teaching and learning during online setting in the times of pandemic.

Teaching ESP in a normal situation is very challenging and requiring strong effort from the teachers themselves, and in times of emergency during this pandemic, it is getting harder and more challenging. Teaching ESP have to use a special topic appropriate to the occupied areas of learners' study (Kultsum \& Arsadani, 2014) and there is a deep dissimilarity between designing remote learning or hybrid course, and having to promptly adjust on-campus courses to bring them accessible (Cor \& Coutherut, 2020). Students' need analysis is being the prior step that the teachers of ESP should be taken as an important consideration to design material and select the best teaching method or technique, particularly selecting the best practice of teaching ESP during COVID-19 outbreak. ERL demands circumstances different from common situations since the students had not been prepared in terms of technical infrastructure and digital literacy. Lack of preparation by the schools, students, and their parents is the core problem in distance education carried out during the pandemic (Misirli \& Ergulec, 2021). Looking into these circumstances, teaching ESP has another perspective dealing with the strategies used in online learning and crisis. Teachers should take deep and wide consideration of the objectives, instructions, methods, and tools used in the online learning process.

Hutchinson and Waters (1987) described ESP as a method to language teaching in which all choices as to content and methods are based on the learner's reason for learning". Through this, Yulia \& Agustiani (2019) concluded that ESP was mostly recognized as a learner-centered approach, because it encountered the needs of adult learners who wanted to learn a foreign language use in their specific fields, such as nursing, science, technology, hospitality, academic learning, etc. In other words, teaching ESP should accommodate the students' demands, and its process links to the real world of a workplace in the future self-career. Of course, teaching ESP in recent years has been full of challenges, especially during an emergency due to a virus outbreak that forced the education system to change its learning method from face-to-face to distance learning. For these extents, providing references of best practices of ESP teaching techniques was very essential so that the ESP lecturers could perform very well during online lesson and help the students to achieve the goals of learning.

According to some studies with the scope and limitation of pandemic situation, ESP teachers have been developing and implementing various strategies of teaching techniques meeeting to the students' need and goals, for example, flipped classroom, problem-based learning, project-based learning, synchronous \& asynchronous mixing technique, WhatsApp-based learning (Betaubun, 2021; Kusumawati, 2020; Mandasari \& Wulandari 2020; Ardhyantama, 2020). Designing proper and appropriate English materials and techniques as well as the activities for ESP, played a prominent role (Nimasari et al., 2019) so that the learning goals could be achieved successfully, particularly in the context of ERL. ESP teachers are struggling in constructing English online instructions during COVID-19 pandemic. There are, until now, lots of challenges and impediments faced by and they need to be solved in a short of time. In the past half and year, ESP teachers also did trials and errors in developing teaching techniques and its activities to meet students' needs and learning objectives until they found the best ESP practice. This statement in line with the opinion of William (2020) who said that it is a difficult thing for teachers to design lessons and scheme academically aligned language 
improvement activities and quite difficult to reproduce those activities during remote learning. Based on this fact, there was very limited information about best references of teaching tecniques for ESP field to help the teachers to perform in the online learning during COVID-19 or emergency situation. The purpose of this article was to present some best practices of teaching ESP in the context of emergency remote learning (ERL) and it provided recent information regarding teaching ESP and learning experience for the students of specific purposes.

\section{METHODS}

The aim of this study was to find out the opinions, perceptions, and preferences of a group of ESP lecturers of their best practices in teaching ESP in the times of emergency remote teaching and learning due to COVID-19 outbreak so that a survey research design was designed in this study. Survey research is normally used to describe point of views, attitudes, preferences, and perceptions of large population of interest to the researcher (Latief, 2011). Through a survey research, the writer would get a representative data of large population and fairly simple to tabulate and analyze. The respondent was a group of ESP lecturers consisted of 23 lecturers at some universities in Java, namely STIKES Widyagama Husada; Universitas Pelita Harapan; Universitas Islam Indonesia Yogyakarta; Institut Teknologi Dirgantara Adisucipto Yogyakarta; Sekolah Tinggi Pariwisata Ambarukmo Yogyakarta; Universitas Muhammadiyah Yogyakarta; STIKES Madani Yogyakarta; Sekolah Tinggi Teknologi Kedirgantaraan; STIE Solusi Bisnis Indonesia; Universitas Mercu Buana Yogyakarta; Poltekkes Kemenkes Yogyakarta.

The instrument of this study was an online questionnaire constructed by the writer based on the literature review regarding the topic of research. There were 9 items included corresponding to the best practice of teaching ESP. Those were (1) name of the study program and institution; (2) ESP area; (3) ESP: best practice; (4) The description of best practice; (5) the rationale; (6) language skill target; (7) types of learners; (8) student's response; (9) the challenges and solutions. Those questions aimed to figure out what best practices that ESP leacturers used during learning from home in the times of emergency and the responses were collected to be highlighted in the form of table and then contrasted to the theories of previous studied. This is the link to the questionnaire http://bit.ly/Teaching-ESPBest-Practice. The research data were collected from the questionnaire administered to the ESP teachers' community of WhatsApp Group. They filled out the form and the response was recorded in the form of a spreadsheet and after that, the writer conducted data analysis. The data collected from the questionnaire were analyzed in three phases: data reduction, data display, and conclusion. The writers selected the data that met the scope of research and simplified them to be displayed in the form of a table. Then, the writers drew a conclusion based on the purpose of the study.

\section{FINDINGS AND DISCUSSION}

In higher education, ESP is one of the approaches to teach English for non-native speakers and nonEnglish departments because it is considered tailoring the students' needs and real-world careers. Waicekawsky et al., (2020) stated that most universities have included the ESP program as part of their syllabuses because they acknowledge the importance of helping non-native students of English met to their disciplines and professions. At this time, however, teaching ESP is quite struggling and needs much effort. Teachers and students are facing lots of challenges during learning from home due to the pandemic. Even, in ordinary times, to build meaningful and appropriate learning, the teachers of ESP frequently was demanded to create some innovations and revolutions. In classroom practice, the common activities embrace dialogue, sharing, role-play, lectures, doing exercises to facilitate learners to master the materials (Prabandari et al., 2016). To help them meet students' needs and goals during this outbreak of COVID-19, ESP teachers provided some best practices dealing with English online learning. As following in Table 1, here was the best practices of ESP teaching during COVID19.

Table 1. Best Practices of ESP Teaching during COVID-19

\begin{tabular}{|c|c|c|c|c|c|c|}
\hline \multicolumn{7}{|c|}{ Items of Questionnaire } \\
\hline & ESP Field & Best Practice & Rationale & $\begin{array}{l}\text { Language } \\
\text { Skill Target }\end{array}$ & $\begin{array}{l}\text { Type of } \\
\text { Learner }\end{array}$ & $\begin{array}{l}\text { Learners' } \\
\text { Response }\end{array}$ \\
\hline 1 & $\begin{array}{l}\text { English for } \\
\text { Nursing }\end{array}$ & $\begin{array}{l}\text { Indovidual } \\
\text { Listening } \\
\text { Exercise }\end{array}$ & $\begin{array}{l}\text { Contextual } \\
\text { Material \& } \\
\text { Learning } \\
\text { Autonomy }\end{array}$ & $\begin{array}{l}\text { Listening } \\
\text { skill }\end{array}$ & $\begin{array}{l}\text { Fast } \\
\text { learners }\end{array}$ & Good \\
\hline
\end{tabular}




\begin{tabular}{|c|c|c|c|c|c|c|}
\hline 2 & ESP for Nursing & $\begin{array}{l}\text { 4/3/2 Speaking } \\
\text { Technique }\end{array}$ & $\begin{array}{l}\text { Repetition } \\
\text { activity and } \\
\text { improving } \\
\text { speaking }\end{array}$ & $\begin{array}{l}\text { Speaking \& } \\
\text { Listening } \\
\text { Skill, } \\
\text { Grammar \& } \\
\text { Vocabulary }\end{array}$ & $\begin{array}{l}\text { Fast } \\
\text { Learners }\end{array}$ & $\begin{array}{l}\text { Very } \\
\text { good }\end{array}$ \\
\hline 3 & $\begin{array}{l}\text { ESP for } \\
\text { Engineering }\end{array}$ & Scaffolding & $\begin{array}{l}\text { Simple \& } \\
\text { applicable }\end{array}$ & $\begin{array}{l}\text { Integrated } \\
\text { langauge } \\
\text { skill }\end{array}$ & $\begin{array}{l}\text { Slow } \\
\text { leaners }\end{array}$ & $\begin{array}{l}\text { Very } \\
\text { good }\end{array}$ \\
\hline 4 & $\begin{array}{l}\text { ESP for } \\
\text { Engineering, } \\
\text { Tourism }\end{array}$ & $\begin{array}{l}\text { Project Based } \\
\text { Learning }\end{array}$ & $\begin{array}{l}\text { Real world \& } \\
\text { Meaningful } \\
\text { experience }\end{array}$ & $\begin{array}{l}\text { Integrated } \\
\text { language } \\
\text { skill }\end{array}$ & $\begin{array}{l}\text { Both fast } \\
\& \text { slow } \\
\text { learners }\end{array}$ & Good \\
\hline 5 & Business English & $\begin{array}{l}\text { Zoom Breakout } \\
\text { Room }\end{array}$ & $\begin{array}{l}\text { Utilizing } \\
\text { digital tool for } \\
\text { improving }\end{array}$ & $\begin{array}{l}\text { Speaking } \\
\text { skill }\end{array}$ & $\begin{array}{l}\text { Fast \& } \\
\text { Slow } \\
\text { Learners }\end{array}$ & Good \\
\hline 6 & $\begin{array}{l}\text { Business English } \\
\& \text { Tourism }\end{array}$ & Role Play & $\begin{array}{l}\text { Practical, } \\
\text { Contextual }\end{array}$ & $\begin{array}{l}\text { Speaking \& } \\
\text { Writing skill }\end{array}$ & $\begin{array}{l}\text { Fast \& } \\
\text { Slow } \\
\text { Learners }\end{array}$ & Good \\
\hline 7 & $\begin{array}{l}\text { English for } \\
\text { Aviation }\end{array}$ & $\begin{array}{l}\text { Research best } \\
\text { learning }\end{array}$ & $\begin{array}{l}\text { Conceptual \& } \\
\text { meaningful }\end{array}$ & $\begin{array}{l}\text { Speaking \& } \\
\text { listening } \\
\text { skill }\end{array}$ & $\begin{array}{l}\text { Fast \& } \\
\text { Slow } \\
\text { learners }\end{array}$ & $\begin{array}{l}\text { Very } \\
\text { goo }\end{array}$ \\
\hline 8 & $\begin{array}{l}\text { ESP for } \\
\text { Mechanical } \\
\text { Engineering }\end{array}$ & $\begin{array}{l}\text { Contextual } \\
\text { Reading } \\
\text { Comprehension } \\
\text { Material }\end{array}$ & $\begin{array}{l}\text { Introducing } \\
\text { topics based } \\
\text { on students' } \\
\text { need }\end{array}$ & $\begin{array}{l}\text { Reading } \\
\text { skill }\end{array}$ & $\begin{array}{l}\text { Slow } \\
\text { learners }\end{array}$ & Good \\
\hline 9 & $\begin{array}{l}\text { Business } \\
\text { Communication }\end{array}$ & $\begin{array}{l}\text { Project Based } \\
\text { Learning } \\
\text { (business plan) }\end{array}$ & $\begin{array}{l}\text { Interesting \& } \\
\text { promoting } \\
\text { creativity }\end{array}$ & $\begin{array}{l}\text { Speaking, } \\
\text { writing, } \\
\text { vocabulary } \\
\text { \& Grammar }\end{array}$ & $\begin{array}{l}\text { Fast \& } \\
\text { Slow } \\
\text { learners }\end{array}$ & Good \\
\hline 10 & Business English & $\begin{array}{l}\text { Problem-Based } \\
\text { Learning }\end{array}$ & $\begin{array}{l}\text { Connecting } \\
\text { the real world, } \\
\text { promoting } \\
\text { critical } \\
\text { thinking }\end{array}$ & $\begin{array}{l}\text { Speaking, } \\
\text { Grammar \& } \\
\text { Vocabulary }\end{array}$ & $\begin{array}{l}\text { Fast \& } \\
\text { Slow } \\
\text { learners }\end{array}$ & Good \\
\hline 11 & $\begin{array}{l}\text { English for } \\
\text { Islamic Law }\end{array}$ & Flipped Learning & $\begin{array}{l}\text { Based on } \\
\text { students' } \\
\text { characteristic }\end{array}$ & $\begin{array}{l}\text { Reading } \\
\text { skill }\end{array}$ & $\begin{array}{l}\text { Slow } \\
\text { learners }\end{array}$ & Good \\
\hline 12 & $\begin{array}{l}\text { ESP for Blood } \\
\text { Bank Technology }\end{array}$ & $\begin{array}{l}\text { Utilizing } \\
\text { Learning } \\
\text { Management } \\
\text { Sustem }\end{array}$ & $\begin{array}{l}\text { Mixing } \\
\text { various types } \\
\text { of LMS }\end{array}$ & $\begin{array}{l}\text { Writing \& } \\
\text { Reading } \\
\text { skill }\end{array}$ & $\begin{array}{l}\text { Fast \& } \\
\text { Slow } \\
\text { Learners }\end{array}$ & $\begin{array}{l}\text { Very } \\
\text { good }\end{array}$ \\
\hline
\end{tabular}

Based on Table 1, it was found some information regarding with best practices of teaching ESP during emergency remote learning due to COVID-19 outbreak, such as individual learning activities, 4/3/2 speaking technique, scaffolding technique, project-based learning, Zoom breakout room activities, role play, research-based learning, contextual-reading text activities, problem-based learning, flipped learning and utilizing three online platforms. Here was the highlight of ESP teaching techniques used by some ESP lectures compiled from the result of questionnaire:

\section{Individual exercises activities}

This technique was used in ESP for nursing at STIKES Widyagama Husada. The activities aimed to promote autonomous learning of the students in learning English. The teacher/lecturer assigned various activities to do exercises taken from certain websites accompanied by an answer key and various activities. This technique has the benefit of contextual materials and improves students' listening skills. It suits the fast learners' type. According to the result, students pointed out that this technique was good with some challenges such as internet connection and students' commitment to learning.

\section{4/3/2 speaking technique}

ESP for nursing at Pelita Harapan University also employed this method. 4/3/2 speaking technique has the main purpose in enhancing speaking skills. In the times of COVID-19 pandemic, the teacher utilized Zoom Breakout Room as a learning tool. She/he assigned the students to make a poster and 
present it in three rounds. The first round was 5 minutes, the second round was 4 minutes, and the last round was 3 minutes. The repetition activity was one of the opportunities to practice English speaking skills and fluency. This technique is good for fast learners and students' response towards this activity was very good. Some challenges that they faced was the internet connection.

\section{Scaffolding technique}

The English lecturer at the Islamic University of Indonesia employed this in ESP for engineering. Scaffolding has strengths that are very simple and applicable. Besides that, it covers more than one language skill (speaking, writing, and reading). The teachers commonly maximize the advocacy and practice with constructive feedback to get optimal output. Through these techniques, teachers can also utilize and mix two or more platforms to help the teacher maximizing the scaffolding. It is very good for slow learners with some challenges such as too many exercises, practices, and revisions, but those could be solved by keeping the students' motivated. The response towards this technique was very good.

\section{Project-Based Learning}

Some universities used Project-Based Learning in ESP for engineering, tourism, and aviation engineering, one of them at Institute Teknologi Dirgantara Adisucipto and Sekolah Tinggi Pariwisata Ambarukmo. This learning method aims to engage and to give lots of meaningful experiences met to the real world of students' disciplines. Through this, students learn speaking and writing skills, as well as grammar and vocabulary. Project-based activities are very suitable to the fast and slow learners with some challenges during this outbreak of Coronavirus, such as internet connection, presentation, and authentic material access difficulty.

\section{Zoom breakout room activities}

This best practice was used at Muhammadiyah University and STIKES Madani Yogyakarta. Due to COVID-19, Zoom is booming among learners and teachers because it provides synchronous activities by utilizing its features. Breakout room and recording features are some of the favorite ones to facilitate the students in practicing speaking skills and communication. Teachers frequently assigned the students to work or learn in a group and discuss the topic with others through Zoom Meeting. Students' response towards this technique was good and it can help them mastering speaking skills. One of the challenges that teachers and students face in using Zoom Cloud Meeting application was the internet connection.

\section{Research-based learning}

Sekolah Tinggi Teknologi Kedirgantaraan used this best practice of ESP for aviation. The aim was to help the students strengthening the research concept in the aviation field through direct communication or conversation with foreigners using English. The students were assigned to interview some foreigners based on the questionnaire with a certain topic of aviation. This technique is very good to improve speaking and listening skill. Two types of learners, fast and slow, had a very good response to this with a challenge of students' confidence. In times of crisis, the interview was delivered online and focus on reading and writing skills.

\section{Contextual-reading text activities}

The Muhammadiyah University of Yogyakarta used this ESP for Mechanical Engineering. The initial purpose was to introduce ESP to the students using simple text corresponding with mechanical engineering. This activity was focusing on reading comprehension such as finding the main idea, detailed information, and so forth. Slow learners had a good response to this technique with a challenge of low level of reading motivation. The teachers solved this problem by having a group discussion and reading exercises.

\section{Problem-Based Learning}

This model was used by STIE Solusi Bisnis Indonesia and Universitas Mercu Buana Yogyakarta in ESP for business and PBL was considered promoting students' critical thinking by having a discussion, analysis, and decision making. Speaking skills, grammar, and vocabulary were the language focuses of this technique. In addition to that fast and slow learners had a positive response 
to this. One of the biggest challenges was students' low level of confidence in giving opinions and the solution was peer studying and tutoring.

\section{Flipped learning}

This technique was used for students at Islamic Law Department and Poltekkes Kemenkes Yogyakarta to enhance their reading skills. The learning materials were previously delivered to the students using the online platform. They learned and did the initial language target after that students and teachers had restricted face-to-face meetings to have follow-up activities regarding the topics they learned in advance online. Slow learners had a good response to the activities of flipped learning. One of the challenges was the quality of the internet connection.

\section{Utilizing 3 online platforms}

This model was applied in the department of Blood Bank Technology. The teachers combined three media of learning platforms. The first was Edlink to present the instructions and delivered some assignments. The second media was Zoom Cloud Meeting for teacher's explanations and to practice certain language skills. The third media was Telegram or social media to have interactive communication in the mode of distance learning by delivering quizzes/polls. The advantages of this technique were more interactive, avoiding overload tasks, and fostering students' motivation in learning English in the time of COVID-19. The skill enhancement was on reading and writing skills. Fast and slow learners had a good response to this technique and one of the challenges was the internet connection.

During the outbreak of Coronavirus, the face-to-face classroom was moved into distance learning, including the system in higher education. All ESP teachers dealt with this situation to find the best strategy to give the students an optimal learning environment even though it was served through the internet connection. The scaffolding technique was alternatively considered to be very significant in preparing the students for greater independence and autonomy, because instructional scaffolding assisted students to navigate coursework and achieve tasks they, otherwise, might not have been able to (Shaw, 2019). Pointed out to this statement, the scaffolding technique was very helpful to the students, particularly slow learners, to complete online tasks during English language learning in the time of pandemic and this technique became one of the best practices in teaching ESP. Through this experience, the students were promoted to have independence and autonomy or led to having individual learning practice in enriching the knowledge of English according to their field of language learning.

Another principle of ESP context was that teaching ESP should cover both theoretically and practically (Indrasari, 2016), it meant that the process of learning for ESP students had to involve the real experience that would be faced by them. Project-based learning aimed to prepare the students to have meaningful experiences by implementing the theory they got in the classroom. In addition to this technique, a study found another best practice, namely problem-based learning. It also had a positive response from the students in language learning. From students' point of view, it fostered students' critical thinking, collaboration, and independence (Susanti, 2014). ESP teaching as a bridge between the classroom and the real world should design various activities that accommodate students' need for 21st skills. In another word, project-based learning and problem-based learning could become best practices in ESP that can be implemented face-to-face or online. In the times of COVID-19, the tools for those methods could be determined based on the goals of learning, and ESP teachers can select to have the synchronous or asynchronous mode.

During the pandemic, English teachers were taking so many considerations in selecting the best tool of learning. There are lots of abrupt online learning tools, such as Zoom Cloud Meeting, Google Meet, Google Classroom, Flipgrid, Skype, Moodle, and so forth. Among them, Zoom Cloud Meeting is one of the popular platforms used as a learning medium since this application provides live learning activities synchronously and supports communication needs with people anywhere and anytime without meeting physically (Laili \& Nashir, 2020). This platform has some useful features, two of them are breakout room meetings and recording. Using these features, students are assigned to have private performances in small group work and watch their recording performance at their own pace. So, in the times of online meetings, breakout room and recording serve best for practicing and enhancing speaking and listening skills just like in the face-to-face classroom. The result of this article supported the findings above that Zoom breakout room and recording feature would be the best 
practice in speaking and listening skills during online instructions in the context of emergency remote learning with its drawbacks and benefits.

English for Specific Purposes (ESP, hereafter) has specific involvement in designing English words and activities connected to a specific discipline. This approach supports a group of learners to meet their English requirements that generally refers to the demand in the place of work (Nimasari et al., 2019). In this respect, the use of authenticity will be very much suggested (Purwanto \& Nurhamidah, 2021) and supporting this statement that ESP teachers should provide effective course design that was suitable for learners' reason of learning (Yulia \& Agustiani, 2019). Based on these points, assigning ESP students with contextual reading text was a good choice to help them learn the real world of their work in their future careers. In addition to the findings above, another study pointed out that flipped learning was suitable for English of Engineering since it is very potential to combine the conceptual ability and learning behavior corresponding to the topic of language learning (Karabulut-Ilgu et al., 2017). This statement in line also with the point of view of flipped learning that it was particularly well suited in the mode of transition, and students' attitude towards this was good and positive because it could enhance learning motivation, engagement, and effectiveness (Nouri, 2016). Based on this result, flipped learning was one of the best ways and practices to teach ESP, particularly in times of emergency due to Coronvirus outbreaks, which provided the students with a combination of onsite and online learning techniques. Overall, flipped learning was very appropriate to the slow learners' type or slow achievers (Nouri, 2016).

The last discussion about best practices in ESP was about the utilization of three (3) online platforms to support students' activities when doing learning from home. In the first year of 2020, the beginning of COVID-19 demanded classroom learning to be moved into bursting internet-based learning at home. It is a challenge for ESP educators to run the learning process from face-to-face to online at once. Utilizing various platforms helped the students to avoid overload tasks and boredom, as well as to create an attractive learning environment. Besides that, the combination of two or three platforms in a series of an online meetings promoted students' motivation also. In this context, ESP teachers designed tasks and activities through a different platform, for example using LMS for delivering instructions/materials; using Zoom Cloud Meeting to have a live discussion based on the materials delivered; and at last, using Telegram to have followed up activities (evaluation and feedback). In implementing this best practice, teachers need to be digitally literate.

As it has been discussed before, best practices in ESP should think through an aspect, namely type of learners. There are different types of language learners, such as fast learners and slow learners. This learning background became one of the considerations of ESP teachers in designing English courses including the teaching technique/method (Zakarneh et al., 2020), particularly in the context of emergency remote learning during COVID-19 and internet-based learning. The teaching methods/techniques had to meet students' outcomes in mastering four language skills (speaking, writing, listening, and reading) and two language components (grammar \& vocabulary).

\section{CONCLUSION}

COVID-19 pandemic came up with abrupt changes and resiliences among students, teachers, and stakeholders. The education system that had to be implemented in the middle of a crisis demanded quick responses from the teachers, particularly ESP teachers. The ESP teachers had to response fast about designing online instructions or learning from home with web-based instructions. The materials and activities designed had to follow the emergency but still accommodated the learning process to achieve the goals. The teaching strategy of English language teaching used by the ESP teachers covered all students' needs in learning English for the next career. Finding the best practice in teaching ESP was such kind of challenge in the process of delivering online instructions, but through trials and errors, planning, and evaluation, ESP teachers found the best way to teach the students in the context of ESP in emergency remote learning. English for Specific Purposes is another way of language teaching in which all processes depend on students' needs, meaning that considering students' requirements is an obligation before the teaching and learning process begins, mainly during emergency remote learning because of the pandemic of COVID-19. Therefore, all stakeholders must support and take part according to their capacity to create a better learning environment in the middle of the crisis and help students meeting the goals of learning successfully. 


\section{ACKNOWLEDGEMENT}

The researchers want to thank to all the supports from Poltekkes Kemenkes Malang, friends, lecturers and all parties who had supported this research, so this research can be finished by the researchers on time.

\section{REFERENCES}

Ardhyantama, V., Apriyanti, C., \& Erviana, L. (2020). Project-Based Learning as the Alternative for Distance Learning in COVID-19 Outbreak. Indonesian Journal of Primary Education, 4(2), pp. 141-151 https://ejournal.upi.edu/index.php/IJPE/article/view/26979/13583

Betaubun, M. (2021). The Students' Attitude and Learning Experience toward Flipped Classroom Implementation in ESP Class During COVID-19 Outbreak: A Survey Study. Jurnal Pendidikan Progresif, 11(1), pp. 54-62. http://jurnal.fkip.unila.ac.id/index.php/jpp/article/view/21824 http://dx.doi.org/10.23960/jpp.v11.11.202105

Cor, G. L., \& Coutherut, M. (2020). Online Courses in Times of Pandemic: ESP and Applied English Classes at Université Paris 8. Open Edition Journals, pp. 7-17. https://doi.org/10.4000/asp.6481

Hodges, C., Moore, S., Lockee, B., Trust, T., \& Bond, A. (2020). The Difference between Emergency Remote Teaching and Online Learning. Retrieved from https://er.educause.edu/articles/2020/3/thedifferencebetweenemergencyremoteteachingando nlinelearning?utm_source $=$ Selligent\&utm_medium $=$ email\&utm_campaign $=t 1 \_n e w s l e t t e r \& u t m$ _content $=4720 \& u$ tm_term $=$ body_\&m_i $=$ NcWN9rE9v0WAu1BSCHwDldQZyv3Hok3hCWF 4XWN28kQs9\%2BDV8iAh5OWfC6t5366n1t27PiSgdsEra8EKclfVz5e0v\%2BJhSslU8

Hutchinson, T. \& Waters, A. (1987). English for specific purposes: A Learning Centered Approach. New York: Cambridge University Press.

Indrasari, N. (2016). English for Specific Purposes: A Need Analysis at the Second Semester of Physics Education Students of IAIN Raden Intan Lampung in The Academic Year of 2015/2016. Jurnal Tadris Bahasa Inggris, 9(1), pp. 161-172 https://doi.org/10.24042/eejtbi.v9i1.425

Iswati, L. (2020). When Teaching Must Go On: ESP Teachers' Strategies and Challenges during COVID-19 Pandemic. Eralingua: Jurnal Pendidikan Bahasa Asing dan Sastra, 5(1), pp. 36-52, E-ISSN : 25794574. https://ojs.unm.ac.id/eralingua

Karabulut-Ilgu, A., Cherrez, N. J., \& Jahren, C. (2017). A Systematic Review of Research on the Flipped Learning Method in Engineering Education. British Journal of Educational Technology, 49(3), pp. 398411. DOI: $10.1111 /$ bjet. 12548

Kultsum, U., \& Arsadani, Q. (2014). Instructional Design in Teaching English for Law. Jurnal Filsafat dan Budaya Hukum, pp. 257-266. https://www.academia.edu/9997988

Kusumawati, A. J. (2020). Redesigning Face-to-Face into Online Learning for Speaking Competence during COVID-19: ESP For Higher Education In Indonesia. International Journal of Language Education, 4(2), pp. 276-288. https://doi.org/10.26858/ijole.v4i2.14745

Laili, R. N., \& Nashir, M. (2020). The Use of Zoom Meeting for Distance Learning in Teaching English to Nursing Students during Covid-19 Pandemic. Presented at UHAMKA International Conference on $\begin{array}{llll}\text { ELT and } & \text { CALL(UICELL), }\end{array}$ https: $/ /$ www. google. com $/$ url? $s a=t \& r c t=j \& q=\& e s r c=s \&$ source $=w e b \& c d=\& c a d=r j a \& u a c t=8 \& v e d=2 a h U$ KEwiIg8jDxJHxAhUNILcAHWRxDx0QFjAQegQIEhAE\&url=https\%3A\%2F\%2Fjournal.uhamka.ac. id\%2Findex.php\%2Fuicell\%2Farticle\%2Fdownload\%2F6290\%2F2138\%2F\&usg=AOvVaw08oD8qXM EEy 3 NFMMTPSIKt

Latief, M. A. (2011). Research Methods on Language Learning. An Introduction. Malang: Malang University Press.

Mandasari, Y., \& Wulandari, E. (2020). Online-English Learning for Nursing Students in the Times of COVID 19 Pandemic (Perceptions and Challenges in ERT Context). Prosiding Seminar Nasional Industri Bahasa 2020. Jakarta: PNJ Press

Misirli, O., \& Ergulec, F. (2021). Emergency Remote Teaching during the COVID-19 Pandemic: Parents Experiences and Perspectives. Educ Inf Technol (Dordr). 2021 Mar 29:1-20. Epub ahead of print. PMID: 33814956; PMCID: PMC8006625. https://doi.org/10.1007/s10639-021-10520-4

Nimasari, E. P., Mufanti, R., \& Gestant, R. A. (2019). Designing English for Specific Purpose Materials: A Preliminary Coursebook Product for Informatics Engineering Context. Journal of English Educators Society, 4(3), pp. 61-68. https://doi.org/10.21070/jees.v4i2.2526 
Nouri, J. (2016). The Flipped Classroom: for Active, Effective And Increased Learning - Especially for Low Achievers. International Journal of Educational Technology in Higher Education 13, pp. 33. https://doi.org/10.1186/s41239-016-0032-z

Prabandari, C. S., Aji, G. P., \& Yulia, M. F. (2016). A Learning Model Design Integrating ESP Course and Service Learning Program to Promote Relevance and Meaningfulness. A Journal on Language and Language Teaching, 19(2), pp. 82-88. https://doi.org/10.24071/11t.2016.1902O2

Purwanto, S., \& Nurhamidah, I. (2021). Digitizing English for Specific Purposes in the Era of COVID-19 Pandemic. Journal of Linguistics and Education, 11(1), pp. 57-72. http://ejournal.undip.ac.id/index.php/parole

Shaw, A. (2019). Scaffolding Learning in the Online Classroom. Wiley Education Services. Retrieved from https://ctl.wiley.com/scaffolding-learning-in-the-online-classroom/

Susanti, S. (2014). The Learners' Perception of Problem-Based Learning Experience in Seminar on Elt Class. Journal of English Education Program, https://jurnal.unigal.ac.id/index.php/jeep/article/view/1838

UNESCO. (2020). COVID-19 Response-Remote Learning Strategy. Remote Learning Strategy as a Key Element in Ensuring Continued Learning. Retrieved from https://en.unesco.org/sites/default/files/unesco-covid-19-response-toolkit-remote-learningstrategy.pdf

Waicekawsky, L., Laurenti, L., \& Yuvero, F. (2020). Teaching ESP Online during the COVID-19 Pandemic: An Account of Argentinian Students on this Teaching Modality. EDP Sciences Journal. https://doi.org/10.1051/shsconf/20208802002

Williams, C. P. (2020). How Best to Serve English Learners during a Pandemic. The Century Foundation. https://tcf.org/content/commentary/best-serve-english-learners-pandemic/?agreed=1

Yulia, H. \& Agustiani, M. (2019). An ESP Needs Analysis for Management Students: Indonesian Context. Indonesian Educational Administration and Leadership Journal, 1(1), pp. 35-44. https://www.researchgate.net/publication/340645294_An_ESP_needs_analysis_for_manage ment_students_Indonesian_context

Zakarneh, B., Al-Ramahi, N., \& Mahmoud. (2020). Challenges of Teaching English Language Classes of Slow and Fast Learners in the United Arab Emirates Universities. International Journal of Higher Education, 9(1), pp. 256-269 https://doi.org/10.5430/ijhe.v9n1p256 